\title{
GMR
}

\section{Genotyping of SNPs associated with meat tenderness: comparison of two PCR-based methods}

\author{
L.E. López-Rojas ${ }^{1,3}$, L. Patiño-Cadavid ${ }^{2}$, A. López-Herrera ${ }^{3}$ and \\ J.J. Echeverri-Zuluaga ${ }^{3}$
}

${ }^{1}$ Tropical Medicine Group, Instituto Colombiano de Medicina Tropical, CES University, Sabaneta, Colombia

${ }^{2}$ Master's Program in Biological Sciences, School of Science and Biotechnology, CES University, Medellín, Colombia

${ }^{3}$ Biodiversity and Molecular Genetics Group, School of Agricultural Sciences, Universidad Nacional de Colombia, Medellín, Colombia

Corresponding author: L.E. López-Rojas

E-mail: lelopez@ces.edu.co

Genet. Mol. Res. 16 (2): gmr16029635

Received January 31, 2017

Accepted Abril 3, 2017

Published May 18, 2017

DOI http://dx.doi.org/10.4238/gmr16029635

Copyright $(2017$ The Authors. This is an open-access article distributed under the terms of the Creative Commons Attribution ShareAlike (CC BY-SA) 4.0 License.

\begin{abstract}
Single nucleotide polymorphisms (SNPs) carried in calpain (CAPN1), calpastatin (CAST), and leptin (LEP) genes are associated with meat tenderness. Due to the economic importance of this meat quality attribute, the development of fast, reliable, and affordable methods to identify bovine carriers of favorable alleles is of great importance for genetic improvement. Currently, PCRRFLP is accepted as the standard gold method for genotyping SNPs associated with meat tenderness. But these SNPs can be detected by other techniques as high-resolution melting (HRM) analysis - a postPCR method - that offers several advantages and has great application potential in the meat industry. In this study, we standardized, validated, and compared the performance of PCR-HRM to that of PCR-RFLP in
\end{abstract}

Genetics and Molecular Research 16 (2): gmr16029635 
genotyping bovine SNPs associated with meat tenderness: CAPN4751, CAPN316, CAST2959, CAST282, LEPE2FB, and LEPE2JW. We analyzed genotypes of a total of 380 bovines, 110 Bos taurus and 270 Bos indicus. Results obtained with PCR-HRM were consistent with those found by PCR-RLFP. Furthermore, HRM was found to be highly sensitive, and our results confirmed the repeatability (intra-assay precision) and reproducibility (inter-assay precision) of this assay. An internal control for endonuclease activity was created using sitedirected mutagenesis to generate an additional enzymatic restriction point useful to discriminate SNP alleles. Our results show that PCRHRM is an efficient method that produces reliable and rapid results. However, should be had in account that the method of DNA extraction, the quality and quantity of DNA, analyst-related variations, and primer design may generate challenges for allele discrimination.

Key words: DNA quality; Calpastatin; High-resolution melting; Leptin; Calpain; SNP

\section{INTRODUCTION}

Single gene polymorphisms (SNPs) are a common source of genetic variation. SNPs can be detected by several techniques including polymerase chain reaction-restriction fragment length polymorphism (PCR-RFLP), real-time PCR (q-PCR) using labeled probes, mass spectrometry, and sequencing. However, most of these techniques have the drawback of being costly, time-consuming; they can be vulnerable to contamination issues, having low sensitivity and specificity, and in some cases, of restricted availability (Wittwer et al., 2003; Reed and Wittwer, 2004; Zhang et al., 2013). Over the past decade, several reports have suggested that high-resolution melting (HRM) analysis is a simple and sensitive approach to genotyping SNPs, being comparable or superior to other methods (Liew, 2004; Reed and Wittwer, 2004; Reed et al., 2007; Zhang et al., 2013; Druml and Cichna-Markl, 2014). HRM is performed with newly developed second-generation fluorescent nucleic acid dyes that fluoresce upon binding to dsDNA. Compared to the previous generation of dyes, second-generation dyes can be used at higher concentrations and are less inhibitory toward PCR.

To detect genetic variations, HRM analysis - a post-PCR method - takes into account the melting temperature (Tm) and HRM curve profile, a graph of the dissociation kinetics of dsDNA to ssDNA as temperature increases. The HRM analysis approach can detect changes in the PCR product of up to one nucleotide, and allows the identification of singlebase variants (Reed et al., 2007; Kristensen and Dobrovic, 2008; Druml and Cichna-Markl, 2014). To successfully perform this analysis, proper positive controls for each genotype and the sequence of the amplified fragment of interest are required to avoid ambiguous results provided by the presence of unwanted polymorphisms, insertions, or deletions (López-Rojas et al., 2016). HRM has great application potential in the meat industry for quality control, safety and traceability of meat products, detection of pathogens, identification of meat species (Sakaridis et al., 2013), as well as for genotyping SNPs associated with meat tenderness and juiciness, such as those carried by calpain 1 (CAPN1), calpastatin (CAST) (Curi et al., 2010), and leptin (LEP) (Schenkel et al., 2005).

Genetics and Molecular Research 16 (2): gmr16029635 
In bovine, the calpain family of proteins comprises several calcium-dependent cysteine proteases that play an important role in the conversion of muscle to meat (Taylor et al., 1995; Geesink and Koohmaraie, 1999a). One of the members of this family, mu-calpain, has been previously reported in bovine as protein being responsible for meat tenderness (Geesink et al., 2006; Curi et al., 2010). This protein is encoded by the CAPN1 gene (GenBank No. AF248054) located on chromosome 29 (Smith et al., 2000) and carrying several SNPs that have an effect on meat tenderness (Page et al., 2002; White et al., 2005). SNP CAPN316 (AF252504:g.5709C $>\mathrm{G}$ ), located in exon 9, is a product of a $\mathrm{C} / \mathrm{G}$ transversion and leads to the replacement of a glycine by an alanine in the amino acid sequence (Page et al., 2002). On the other hand, SNP CAPN4751 (AF248054:g.6545C > T), located in intron 17 of the catalytic region, is produced by a $\mathrm{C} / \mathrm{T}$ transition (White et al., 2005). Both polymorphisms in the $\mathrm{C}$ allele are associated with greater meat tenderness (Page et al., 2002; White et al., 2005).

On the other hand, calpastatin is a calcium-dependent calpain-specific inhibitor (Goll et al., 1992; Geesink and Koohmaraie, 1999a,b). The sequence coding for calpastatin is the CAST gene (GenBank No. AY008267) and is located on chromosome 7. In this gene, two SNPs have been previously reported to be associated with meat tenderness: CAST2959 and CAST282. The former, CAST2959 (AF159246:g2959G $>A$ ), is located in the 3'-untranslated region (3'-UTR) and results from a G/A transition (Morris et al., 2006). CAST282 (AY008267:g282C $>\mathrm{G}$ ) is located in intron 5 and is a result of a $\mathrm{C} / \mathrm{G}$ transversion (Schenkel et al., 2006). The A allele of CAST2959 (Morris et al., 2006) and the C allele of CAST282 (Schenkel et al., 2006) have been shown to influence meat tenderness positively.

Some genes may have an indirect effect on meat quality traits, such as the obese or LEP gene (GenBank No. U50365), which codes for a hormone expressed in adipose tissue that regulates appetite, weight, body composition, and fat deposition in muscle. This gene is associated with marmoreal meat and thus with meat tenderness (Blevins et al., 2002; Schenkel et al., 2005). The $L E P$ gene is located on chromosome 4 and carries several polymorphisms (Schenkel et al., 2005), among which is E2FB (AY138588:g305C > T), located in exon 2, and is a $\mathrm{C} / \mathrm{T}$ transition that leads to the replacement of an arginine by a cysteine (Buchanan et al., 2002). On the other hand, SNP E2JW (AY138588:g252A $>$ T), localized in exon 2, is an A/T transversion leading to the replacement of a tyrosine by a phenylalanine (Lagonigro et al., 2003). The T allele of these two polymorphisms has been associated with greater intramuscular fat component (Buchanan et al., 2002; Lagonigro et al., 2003; Schenkel et al., 2005).

Thus, in this study, we have compared two PCR-based methods, PCR-RFLP and PCR-HRM analysis, for genotyping SNPs in genes with appropriate roles for meat traits. We had standardized and validated HRM analysis for the genotyping of SNPs carried on CAPN (CAPN316, CAPN4751), CAST (CAST282, CAST2959), and LEP (E2FB, E2JW) genes.

\section{MATERIAL AND METHODS}

\section{Ethics statement}

The Institutional Animal Care and Use Committee (CICUA) at CES University (Project 38, 2013) approved this project.

\section{Population}

A total of 380 bovines of the species Bos taurus $(\mathrm{N}=110)$ and Bos indicus $(\mathrm{N}=$

Genetics and Molecular Research 16 (2): gmr16029635 
270) were included in this study. Peripheral blood $(5 \mathrm{~mL})$ was drawn into vacuum tubes with EDTA as an anticoagulant and stored at $4^{\circ} \mathrm{C}$ until processed. Genomic DNA was extracted from peripheral blood samples using a DNeasy kit following manufacturer's instructions (Qiagen, Hilden, Germany). DNA quantification and quality control were performed by spectrophotometry (Nanodrop, Thermo). To confirm DNA integrity, samples were run on 1\% agarose gel electrophoresis at $60 \mathrm{~V}$ for $40 \mathrm{~min}$, stained with EZ-vision (USA) and photographed under UV light using Epichem System (UVP, Upland, CA, USA). DNA samples were stored at $-80^{\circ} \mathrm{C}$ until processed.

\section{Amplification by PCR}

Primers were designed using GenBank database (Benson et al, 2005) and the Primer 3 software (Untergasser et al., 2012). Primers flanked regions between 123 and 173 bp carrying the following SNPs: CAPN4751, CAPN316, CAST2959, CAST282, LEPE2FB, and LEPE2JW. An internal control for endonuclease activity was created using site-directed mutagenesis to generate an additional enzymatic restriction point by changing one or two nucleotides in the forward primers of each marker (Figure 1 and Table 1). Primer specificity was confirmed using BLAST. SNPs were independently analyzed. A reaction containing $10 \mathrm{ng}$ total DNA, 10 $\mu \mathrm{M}$ primers (Table 1), and $12.5 \mu \mathrm{L}$ Master Mix HRM Genotyping PCR (QIAGEN, Hilden, Germany) was prepared in a final volume of $25 \mu \mathrm{L}$, bringing up the volume with RNAsefree water. Amplification was performed in a Rotor-Gene 6000 Thermocycler (Corbett Life Science, Concorde, NSW, Australia). Samples were pre-heated at $95^{\circ} \mathrm{C}$ for $5 \mathrm{~min}$ and subsequently subjected to 40 cycles: $95^{\circ} \mathrm{C}$ for $10 \mathrm{~s}$ (denaturalization), annealing temperature for each set of primers (Table 1) for $30 \mathrm{~s}$, and $72^{\circ} \mathrm{C}$ for $10 \mathrm{~s}$ (extension).

\section{CAPN4751}

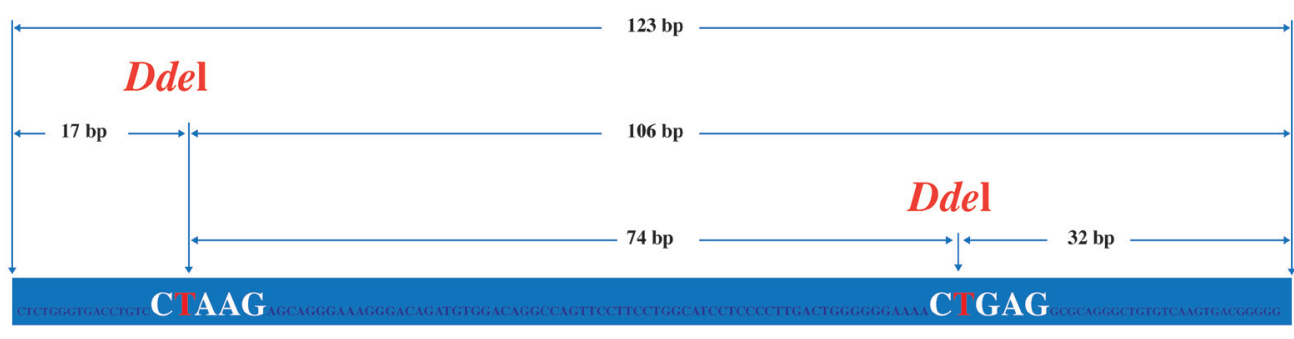

$\mathbf{C} / \mathbf{T}$ $\mathrm{C} / \mathrm{T}$

\section{BTA 29}

Figure 1. Primer design. Schematic illustration of primer design in which a fragment of $123 \mathrm{bp}$ of the CAPN1 gene sequenced, mapped to bovine chromosome 29, carrier of SNP CAPN4751, which induced a restriction point at the 3 ' end for the DdeI (CTNAG) enzyme, and whose digestion generated two fragments ( 32 and $91 \mathrm{bp}$ ) in the T allele. On the $5^{\prime}$ end, a 22-bp sequence was selected as forward primer, in which a $\mathrm{C}$ was switched for a $\mathrm{T}$, thus introducing a second endonuclease restriction point (CTAAG), whose digestion produced three fragments in the T allele (17, 74, and $32 \mathrm{bp}$ ) and two in the $\mathrm{C}$ allele (17 and $106 \mathrm{bp}$ ). Therefore, the 17-bp fragment is an internal control for enzymatic digestion in both alleles.

Genetics and Molecular Research 16 (2): gmr16029635 
Table 1. Primer sequence, annealing temperatures, size of amplicons, and expected digestion products.

\begin{tabular}{|c|c|c|c|c|c|c|c|c|c|c|}
\hline \multirow[t]{2}{*}{$\overline{\text { SNPs }}$} & \multirow[t]{2}{*}{ Chr } & \multirow[t]{2}{*}{ GenBank } & \multirow[t]{2}{*}{ Base } & \multirow[t]{2}{*}{ Motif* } & \multirow[t]{2}{*}{ Sequence $\left(5^{\prime}-3^{\prime}\right)$} & \multirow[t]{2}{*}{$\operatorname{Tm}\left({ }^{\circ} \mathrm{C}\right)$} & \multirow[t]{2}{*}{ Amplicon (bp) } & \multicolumn{3}{|c|}{ Digestion } \\
\hline & & & & & & & & Alleles & Frag (bp) & Enzyme \\
\hline \multirow[t]{4}{*}{$\overline{C A P N 316}$} & \multirow[t]{4}{*}{29} & \multirow[t]{4}{*}{ AF248054 } & \multirow[t]{4}{*}{5709} & \multirow[t]{4}{*}{ TT/GG } & TAGAGGCTGGGCAGGTCAGT $* *$ & 61 & \multirow[t]{2}{*}{113} & C & 40,73 & \multirow[t]{4}{*}{ BtgI } \\
\hline & & & & & CATCTTGACCCGGAGCTGCT ** & 60 & & G & 113 & \\
\hline & & & & & CAGTGCCGTGGTCCTACA & 59 & \multirow[t]{2}{*}{173} & $\mathrm{C}$ & $6,31,136$ & \\
\hline & & & & & \begin{tabular}{|l} 
AGACATGGCACAGCTGGTTT \\
\end{tabular} & 61 & & G & $6,167,173$ & \\
\hline \multirow{2}{*}{$\overline{C A P N 4751}$} & & \multirow{2}{*}{ AF248054 } & \multirow[t]{2}{*}{6545} & \multirow{2}{*}{$\mathrm{C} / \mathrm{T}$} & CTCTGGGTGACCTGTCCTAAGA & 60 & \multirow[t]{2}{*}{123} & $\mathrm{C}$ & 17,106 & \multirow{2}{*}{ DdeI } \\
\hline & & & & & TCCCCCGTCACTTGACAC & 60 & & $\mathrm{~T}$ & $17,32,74$ & \\
\hline \multirow[t]{2}{*}{$\overline{C A S T 282}$} & \multirow[t]{2}{*}{7} & \multirow[t]{2}{*}{ AY008267 } & \multirow[t]{2}{*}{282} & \multirow[t]{2}{*}{$T / C$} & \begin{tabular}{|l|l|} 
TGGCATCAGCAGGTACTGC \\
\end{tabular} & 61 & \multirow[t]{2}{*}{152} & $\mathrm{C}$ & 14,138 & \multirow[t]{2}{*}{ RsaI } \\
\hline & & & & & \begin{tabular}{|l|} 
TTGTGTTTTATGTAGTCAATTGTGAGA \\
\end{tabular} & 59 & & G & $14,67,71$ & \\
\hline \multirow[t]{2}{*}{$\overline{C A S T 2959}$} & & \multirow[t]{2}{*}{ AF159246 } & \multirow[t]{2}{*}{2959} & \multirow[t]{2}{*}{$\mathrm{C} / \mathrm{G}$} & GAAAACGATGCCTCAGGTGT & 60 & \multirow[t]{2}{*}{135} & A & $12,44,79$ & \multirow[t]{2}{*}{ Ddel } \\
\hline & & & & & TGTGCCCAATGCACAGTATT & 60 & & $\mathrm{G}$ & 12,123 & \\
\hline LEPE2FB & 4 & AF 120500 & 73 & $\mathrm{G} / \mathrm{A}$ & \begin{tabular}{|l} 
CGGGAAGGAAAATGCACTG \\
\end{tabular} & 61 & 159 & $\mathrm{~T}$ & $14,71,74$ & HpyCH4V \\
\hline & & & & & CTACCGTGTGTGAGATGTCATTG & 60 & & $\mathrm{C}$ & 14,145 & \\
\hline LEPE2JW & & AY138588 & 252 & $\mathrm{C} / \mathrm{T}$ & GTGTTCTCGGAGATCGATGATG & 61 & 133 & $T$ & 14,119 & Bsul5I \\
\hline & & & & & CGTAAGACAGATAGGGCCAAAG & 60 & & A & $14,34,85$ & \\
\hline
\end{tabular}

Single nucleotide polymorphisms (SNPs), chromosome (Chr), melting temperature (Tm), amplicon size (Amplicon), fragment size of digested products (Frag), change in primer sequence in order to produce a restriction site (Motif*). Red letters are the changes of bases; $(* *)$ unmodified primers.

\section{SNP genotyping by HRM}

A Rotor-Gene $6000\left(\right.$ Corbett $\left.^{\circ}\right)$ equipped with an HRM filter was used. PCR products were subjected to a temperature gradient of $60^{\circ}-80^{\circ} \mathrm{C}$ with gradual increments of $0.05^{\circ} \mathrm{C} / \mathrm{s}$. Normalized melting curves were built using the Rotor-Gene 6000 series $^{\mathcal{O}}$ program (Corbett Life Science).

\section{SNP genotyping by RFLP}

Amplicons were treated with restriction enzymes (Table 1), and incubated in a TC-512 $\left(\right.$ Techne $\left.^{\mathrm{TM}}\right)$ thermocycler, following manufacturer's instructions. Samples were stained with EZ-vision dye and subjected to 1\% low-melting point agarose (type II) gel electrophoresis at $60 \mathrm{~V}$ for $40 \mathrm{~min}$. After electrophoresis, gels were placed on an Epichem System UVtransilluminator to visualize and photograph bands. Sequencing of the fragments amplified by CAPN316 primers was outsourced.

\section{Validation}

HRM genotyping sensitivity, specificity, positive-predictive value, negative-predictive value, repeatability, reproducibility, and robustness were compared to that of RFLP (Table 2) for each of the analyzed SNPs. Sensitivity $(S)$ was defined as the probability of an animal being identified as a carrier of at least one mutated allele (heterozygous and homozygous) by both RFLP and HRM analyses. This was expressed as the ratio of the true positives $(T P)$ and the sum of the $T P$ with the false negatives $(F N)$ and calculated as $S=T P /(T P+F N)$. Specificity $(S P)$ refers to the probability of an animal being identified as a carrier of at least one wild-type allele (heterozygous and homozygous) by both RFLP and HRM. Specificity is expressed as the ratio of the true negatives $(T N)$ and the sum of the $T N$ with the false positives $(F P)$. Thus, specificity was calculated as $S P=T N /(T N+F P)$.

The positive-predictive value (PPV) of the test was defined as the proportion of animals carrying at least one mutated allele (heterozygous and homozygous) identified by both RFLP and HRM: $P P V=T P /(T P+F P)$. 
Table 2. Expected genotyping results by PCR-RFLP and PCR-HRM, illustrated by SNP CAPN4751 analysis.

\begin{tabular}{|c|c|c|c|}
\hline \multirow{2}{*}{\multicolumn{2}{|c|}{ Carrier of $C A P N 4751 \mathrm{~T}$ allele }} & \multicolumn{2}{|c|}{ PCR-RFLP } \\
\hline & & CT, TT & $\mathrm{CC}$ \\
\hline \multirow[t]{2}{*}{ PCR-HRM } & CT, TT & True positives (TP) & False positives (FP) \\
\hline & $\mathrm{CC}$ & False negatives (FN) & True negatives (TN) \\
\hline
\end{tabular}

The negative-predictive value $(N P V)$ was defined as the proportion of animals carrying at least one wild-type allele (heterozygous and homozygous) by both RFLP and HRM: $N P V=T N /(T N+F N)$ (Rubenson et al., 1989; Norambuena et al., 2009). To assess repeatability (intra-assay precision), 10 replicates of each genotype were included in the same run. To determine reproducibility (inter-assay precision), a sample for each genotype was assayed in three different days. To determine robustness of this method, samples for each of the genotypes were processed as follows: variation in DNA concentration $(10,20,50$, and $100 \mathrm{ng})$, variation in annealing temperature $\left( \pm 1^{\circ} \mathrm{C}\right)$, number of PCR cycles ( \pm 2 cycles), and variation in pipetting ( $\pm 0.5 \mu \mathrm{L}$ reaction mix and $\pm 1.0 \mu \mathrm{L}$ DNA) (Norambuena et al., 2009). Furthermore, three independent group members analyzed these samples.

\section{RESULTS}

\section{SNP genotyping by RFLP}

All samples analyzed by PCR-RFLP showed bands of the expected size according to the amplification protocol and the digestion of fragments of bovine genome carrying each of the SNP alleles investigated in our study (Table 1 and Figure 2A, D, G, J, and M). In our study population, the following SNP genotypes could be identified: CAPN316, CAPN4751, CAST282, CAST2959, LEPE2FB, and LEPE2JW (Table 3).

\begin{tabular}{|c|c|c|c|c|}
\hline SNP & SNP class & Homozygous genotypes & $\operatorname{Tm}\left({ }^{\circ} \mathrm{C}\right)$ & Difference* \\
\hline \multirow[t]{2}{*}{ CAPN316 } & 3 & GG & $86.996 \pm 0.019$ & \multirow[t]{2}{*}{0.19} \\
\hline & & $\mathrm{CC}$ & $86.804 \pm 0.016$ & \\
\hline \multirow[t]{2}{*}{ CAPN4751 } & 1 & TT & $84.269 \pm 0.014$ & \multirow[t]{2}{*}{0.78} \\
\hline & & $\mathrm{CC}$ & $85.054 \pm 0.021$ & \\
\hline \multirow[t]{2}{*}{ CAST282 } & 3 & $\mathrm{CC}$ & $72.872 \pm 0.013$ & \multirow[t]{2}{*}{0.04} \\
\hline & & GG & $72.912 \pm 0.007$ & \\
\hline \multirow[t]{2}{*}{ CAST2959 } & 1 & AA & $78.885 \pm 0.031$ & \multirow[t]{2}{*}{0.36} \\
\hline & & GG & $79.246 \pm 0.136$ & \\
\hline \multirow[t]{2}{*}{$L E P E 2 F B$} & 1 & TT & $82.917 \pm 0.135$ & \multirow[t]{2}{*}{0.46} \\
\hline & & $\mathrm{CC}$ & $83.377 \pm 0.033$ & \\
\hline \multirow[t]{2}{*}{ LEPE2JW } & 4 & AA & $83.364 \pm 0.014$ & \multirow[t]{2}{*}{0.41} \\
\hline & & TT & $83.775 \pm 0.024$ & \\
\hline
\end{tabular}

*Difference in melting temperature by PCR, analyzed by HRM.

An internal control for endonuclease activity was created using site-directed mutagenesis to generate an additional enzymatic restriction point, by changing one or two nucleotides in the forward primers of each marker. By doing so, every allele would have a restriction site that could be used as positive control. This approach was successful for all primers, except $C A P N 316$ as it did not amplify with the pair of modified primers, most likely due to the changing of two bases. Therefore, we used previously reported primers (LópezRojas et al., 2016) (Table 1) that lacked this control mechanism. For this set of primers, the genotype was confirmed by sequencing (Figure 3 ).

Genetics and Molecular Research 16 (2): gmr16029635 

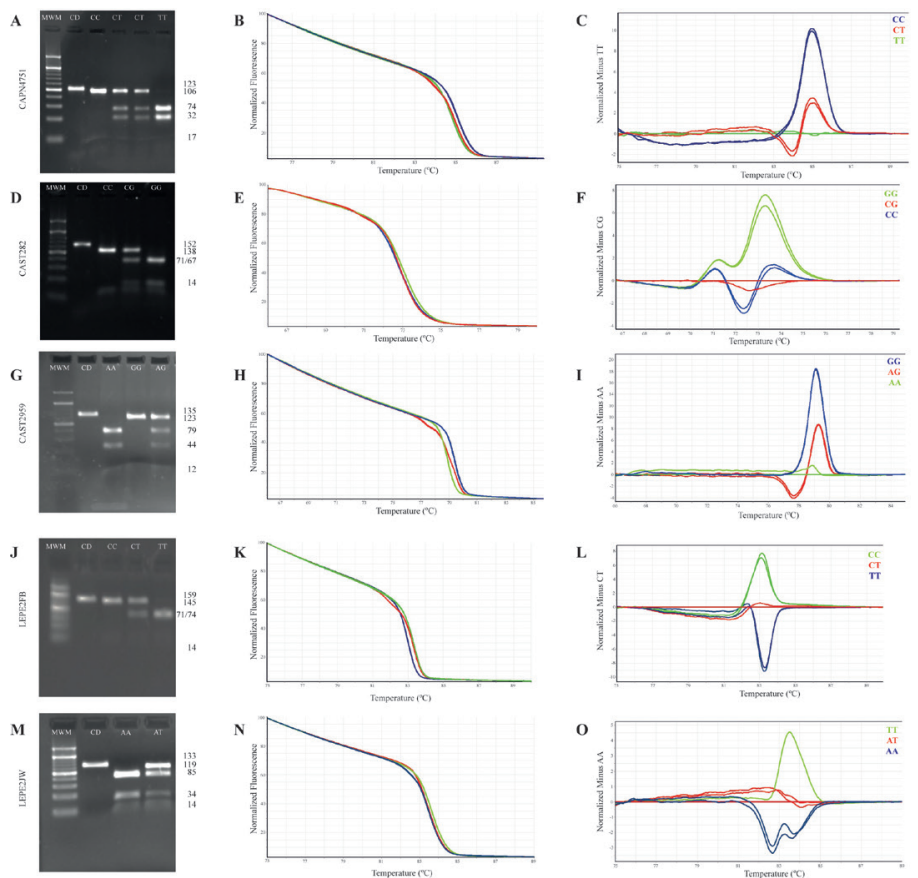

Figure 2. SNPs genotyping. PCR-RFLP (A, D, G, J, and $\mathbf{M})$, HRM melting curves $(\mathbf{B}, \mathbf{E}, \mathbf{H}, \mathbf{K}$, and $\mathbf{N})$, and HRM melting curves normalized to a genotype $(\mathbf{C}, \mathbf{F}, \mathbf{I}, \mathbf{L}$, and $\mathbf{O})$.

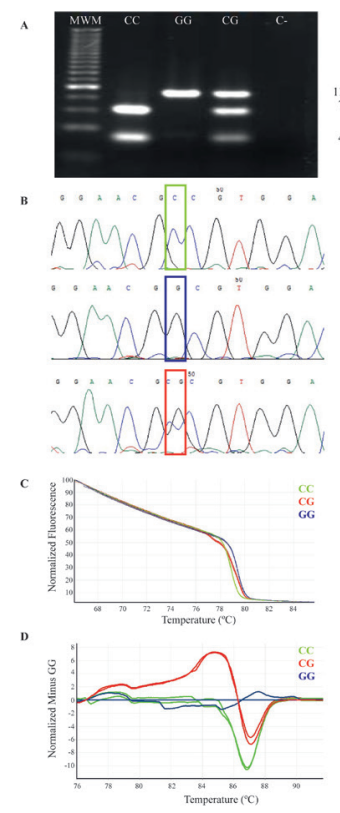

Figure 3. Genotyping of SNP CAPN316. A. Electrophoresis of BtgI digested amplicons; B. sequencing; C. HRM profiles of the different genotypes; D. HRM profile normalized to GG genotype.

Genetics and Molecular Research 16 (2): gmr16029635 


\section{SNP genotyping by HRM}

Samples genotyped by PCR-RFLP were used as positive controls and to characterize melting curves for each genotype. Heterozygous and homozygous genotypes could be identified in the melting curve, where normalized fluorescence was plotted against temperature (Figure $2 \mathrm{~B}, \mathrm{E}, \mathrm{H}, \mathrm{K}$, and $\mathrm{N}$ ). Furthermore, homozygous genotypes were discriminated by plotting the normalized fluorescence against the temperature at which the genotype was used as a normalizer and based on the Tm (Figure 2C, F, I, and O), as well as differences in Tm among genotypes.

\section{Validation}

Results obtained with PCR-HRM were consistent with those found by PCR-RLFP. Furthermore, the PCR-HRM assay exhibited high levels of sensitivity (0.989 to 1.000), specificity $(0.995$ to 1.000$)$, negative-predictive values $(0.954$ to 1.000$)$, and positivepredictive values ( 0.833 to 1.000$)$. These levels were adequate for PCR-HRM (Table 4$)$. Also, as shown in Figure 4, the observed homogeneity of the results confirmed the repeatability (intra-assay precision) and reproducibility (inter-assay precision) of this assay. The assay was optimized and the best experimental conditions for the amplification reaction and HRM are those described in the Material and Methods section. However, the analysis of assay robustness did show that the results could be affected by the analyst, the amount of DNA used, annealing temperature, primer sequence, and reaction volume.

\begin{tabular}{|c|c|c|c|c|c|c|c|c|c|c|c|c|c|}
\hline \multirow[t]{2}{*}{ SNP } & \multirow[t]{2}{*}{ Genotypes } & \multicolumn{2}{|c|}{ RFLP } & \multicolumn{2}{|c|}{ HRM } & \multirow[t]{2}{*}{\begin{tabular}{|l|}
$T P$ \\
\end{tabular}} & \multirow[t]{2}{*}{ FP } & \multirow[t]{2}{*}{ FN } & \multirow[t]{2}{*}{$\mathrm{TN}$} & \multirow{2}{*}{$\begin{array}{c}\mathrm{S} \\
\mathrm{TP} /(\mathrm{TP}+\mathrm{FN})\end{array}$} & \multirow{2}{*}{\begin{tabular}{|c|}
$\mathrm{SP}$ \\
$\mathrm{TN} /(\mathrm{TN}+\mathrm{FP})$ \\
\end{tabular}} & \multirow{2}{*}{$\begin{array}{c}\mathrm{PPV} \\
\mathrm{TP} /(\mathrm{TP}+\mathrm{FP})\end{array}$} & \multirow{2}{*}{$\begin{array}{c}\mathrm{NPV} \\
\mathrm{TN} /(\mathrm{TN}+\mathrm{FN})\end{array}$} \\
\hline & & No. & Freq & No. & Freq & & & & & & & & \\
\hline \multirow[t]{3}{*}{ CAPN316 } & $\mathrm{CC}$ & 6 & 0.02 & 6 & 0.02 & 274 & 0 & 3 & 62 & 0.989 & 1 & 1 & \\
\hline & CG & 59 & 0.16 & 62 & 0.16 & & & & & & & & \\
\hline & GG & 315 & 0.83 & 312 & 0.82 & & & & & & & & \\
\hline \multirow[t]{3}{*}{ CAPN4751 } & $\mathrm{CC}$ & 128 & 0.34 & 127 & 0.33 & 251 & 1 & 0 & 198 & 1 & 0.995 & 0.996 & 1 \\
\hline & CT & 70 & 0.18 & 71 & 0.19 & & & & & & & & \\
\hline & TT & 182 & 0.48 & 182 & 0.48 & & & & & & & & \\
\hline \multirow[t]{3}{*}{ CAST282 } & $\mathrm{CC}$ & 130 & 0.34 & 130 & 0.34 & 250 & 0 & 2 & 295 & 0.992 & 1 & 1 & 0.993 \\
\hline & CG & 167 & 0.44 & 169 & 0.44 & & & & & & & & \\
\hline & GG & 83 & 0.22 & 81 & 0.21 & & & & & & & & \\
\hline \multirow[t]{3}{*}{ CAST2959 } & AA & 178 & 0.47 & 178 & 0.47 & 202 & 0 & 1 & 312 & 0.995 & 1 & 1 & 0.997 \\
\hline & AG & 135 & 0.36 & 134 & 0.35 & & & & & & & & \\
\hline & GG & 67 & 0.18 & 68 & 0.18 & & & & & & & & \\
\hline \multirow[t]{3}{*}{ LEPE2FB } & $\mathrm{CC}$ & 207 & 0.54 & 206 & 0.54 & 172 & 1 & 0 & 359 & 1 & 0.997 & 0.994 & 1 \\
\hline & CT & 152 & 0.40 & 153 & 0.40 & & & & & & & & \\
\hline & TT & 21 & 0.06 & 21 & 0.06 & & & & & & & & \\
\hline \multirow{3}{*}{ LEPE2JW } & $\mathrm{AA}$ & 368 & 0.97 & 366 & 0.96 & 10 & 2 & 0 & 378 & 1 & 0.995 & 0.833 & 1 \\
\hline & AT & 10 & 0.03 & 12 & 0.03 & & & & & & & & \\
\hline & TT & 2 & 0.01 & 2 & 0.01 & & & & & & & & \\
\hline
\end{tabular}

True positive (TP), false positive (FP), false negative (FN), true negative (TN), sensitivity (S), specificity (SP), positive-predictive value (PPV), and negative-predictive value (NPV).

\section{DISCUSSION}

In this study, we have compared two PCR-based methods for SNP genotyping relevant to bovine meat tenderness. In agreement with previous studies (Krypuy et al., 2006; Reed et al., 2007; Druml and Cichna-Markl, 2014), our results show that PCR-HRM is an efficient 


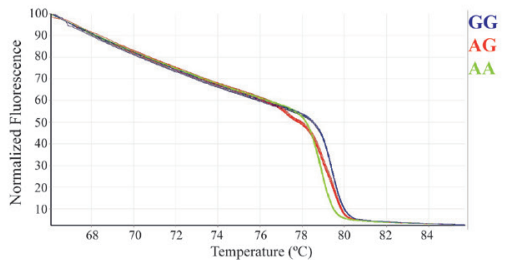

B
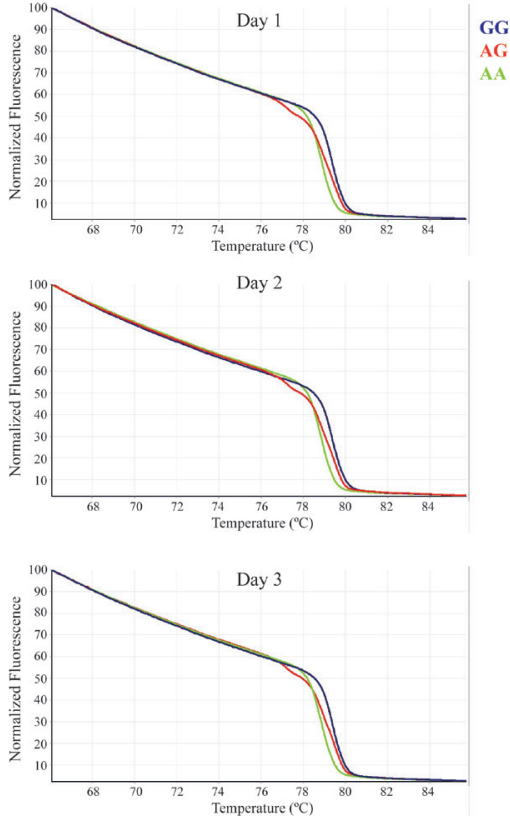

Figure 4. Validation of HRM. A. Repeatability (intra-assay precision) and B. reproducibility (inter-assay precision) are shown for SNP CAST2959.

molecular tool potentially useful for SNP genotyping as it showed high sensitivity, specificity, and robustness. SNPs can be classified according to the type of homoduplex (A/T and G/C) or heteroduplex (A/G, A/C, T/C, and T/G) that is produced by the amplification of heterozygotes; therefore, there are at least four different types of polymorphisms that should be taken into account when designing these assays. Type 1 are $\mathrm{C} / \mathrm{T}$ and $\mathrm{A} / \mathrm{G}$ transitions, such as those found in $C A P N 4751(\mathrm{C} / \mathrm{T}), L E P E 2 F B(\mathrm{C} / \mathrm{T})$, and $C A S T 2959(\mathrm{G} / \mathrm{A})$; type 2 are $\mathrm{C} / \mathrm{A}$ and $\mathrm{G} / \mathrm{T}$ transversions; type 3 are $\mathrm{C} / \mathrm{G}$ transversions, such as that found in CAPN316 and CAST282; and type 4 are T/A transversions, such as that found in LEPE2JW. Even though SNPs belonging to types 3 and 4 could be more challenging to discriminate, as they theoretically have similar Tm both in heterozygotes as in homozygotes, and because it is the same base pair, our results strongly suggest that HRM analysis allows the efficient discrimination of these SNPs.

Altogether, our results show that PCR-HRM is an appropriate method to genotype SNPs relevant for the analysis of bovine meat tenderness including CAPN4751, CAPN316, CAST2959, CAST282, LEPE2FB, and LEPE2JW. With this method, the genotyping by PCRHRM of a total of 380 animals of the Bos taurus and Bos indicus species yielded results

Genetics and Molecular Research 16 (2): gmr16029635 
consistent with genotypes determined by PCR-RLFP and sequencing. Furthermore, we found high levels of specificity and sensitivity, as well as low frequency of false positives and false negatives. Thus, PCR-HRM is an efficient method that produces reliable and rapid results. However, the method for DNA extraction, the quality and quantity of DNA, as well as additional factors, may generate atypical melting curves (data not shown) and false positives or false negatives. Therefore, these variables must be controlled, and the PCR must be closely monitored in order to identify unusual melting curves generated by excess or lack of amplification during the procedure.

\section{Conflicts of interest}

The authors declare no conflict of interest.

\section{ACKNOWLEDGMENTS}

Research supported by grants from the Research and Innovation Division at CES University, and Colciencias grant (\#122870048969).

\section{REFERENCES}

Benson DA, Karsch-Mizrachi I, Lipman DJ, Ostell J, et al. (2005). GenBank. Nucleic Acids Res. 33. D34 D38.

Blevins JE, Schwartz MW and Baskin DG (2002). Peptide signals regulating food intake and energy homeostasis. Can. J. Physiol. Pharmacol. 80: 396-406. http://dx.doi.org/10.1139/y02-035

Buchanan FC, Fitzsimmons CJ, Van Kessel AG, Thue TD, et al. (2002). Association of a missense mutation in the bovine leptin gene with carcass fat content and leptin mRNA levels. Genet. Sel. Evol. 34: 105-116. http://dx.doi. org/10.1186/1297-9686-34-1-105

Curi RA, Chardulo LAL, Giusti J, Silveira AC, et al. (2010). Assessment of GH1, CAPN1 and CAST polymorphisms as markers of carcass and meat traits in Bos indicus and Bos taurus-Bos indicus cross beef cattle. Meat Sci. 86: 915-920 http://dx.doi.org/10.1016/j.meatsci.2010.07.016.

Druml B and Cichna-Markl M (2014). High resolution melting (HRM) analysis of DNA--its role and potential in food analysis. Food Chem. 158: 245-254. http://dx.doi.org/10.1016/j.foodchem.2014.02.111

Geesink GH and Koohmaraie M (1999a). Effect of calpastatin on degradation of myofibrillar proteins by mu-calpain under postmortem conditions. J. Anim. Sci. 77: 2685-2692 http://doi.org/doi:/1999.77102685x. http://dx.doi. org/10.2527/1999.77102685x

Geesink GH and Koohmaraie M (1999b). Postmortem proteolysis and calpain/calpastatin activity in callipyge and normal lamb biceps femoris during extended postmortem storage. J. Anim. Sci. 77: 1490-1501 http://doi.org/ doi:/1999.7761490x. http://dx.doi.org/10.2527/1999.7761490x

Geesink GH, Kuchay S, Chishti AH and Koohmaraie M (2006). Micro-calpain is essential for postmortem proteolysis of muscle proteins. J. Anim. Sci. 84: 2834-2840 http://dx.doi.org/10.2527/jas.2006-122.

Goll DE, Thompson VF, Taylor RG and Zalewska T (1992). Is calpain activity regulated by membranes and autolysis or by calcium and calpastatin? BioEssays 14: 549-556 http://dx.doi.org/10.1002/bies.950140810.

Kristensen LS and Dobrovic A (2008). Direct genotyping of single nucleotide polymorphisms in methyl metabolism genes using probe-free high-resolution melting analysis. Cancer Epidemiol. Biomarkers Prev. 17: 1240-1247. http://dx.doi. org/10.1158/1055-9965.EPI-07-2531

Krypuy M, Newnham GM, Thomas DM, Conron M, et al. (2006). High resolution melting analysis for the rapid and sensitive detection of mutations in clinical samples: KRAS codon 12 and 13 mutations in non-small cell lung cancer. BMC Cancer 6: 295 http://dx.doi.org/10.1186/1471-2407-6-295.

Lagonigro R, Wiener P, Pilla F, Woolliams JA, et al. (2003). A new mutation in the coding region of the bovine leptin gene associated with feed intake. Anim. Genet. 34: 371-374. http://dx.doi.org/10.1046/j.1365-2052.2003.01028.x

Liew M (2004). Genotyping of single-nucleotide polymorphisms by high-resolution melting of small amplicons. Clin. Chem. 50: 1156-1164.

Genetics and Molecular Research 16 (2): gmr16029635 
López-Rojas LE, Patiño-Cadavid L, Martínez-Garro JM, Durán-Ortiz S, et al. (2016). High resolution melting analysis on temperature allows the genotype determination of indicators related to beef. Cub. J. Agr. Sci. 50: 5-10.

Morris CA, Cullen NG, Hickey SM, Dobbie PM, et al. (2006). Genotypic effects of calpain 1 and calpastatin on the tenderness of cooked M. longissimus dorsi steaks from Jersey x Limousin, Angus and Hereford-cross cattle. Anim. Genet. 37: 411-414 http://dx.doi.org/10.1111/j.1365-2052.2006.01483.x.

Norambuena PA, Copeland JA, Krenková P, Stambergová A, et al. (2009). Diagnostic method validation: High resolution melting (HRM) of small amplicons genotyping for the most common variants in the MTHFR gene. Clin. Biochem. 42: 1308-1316 http://dx.doi.org/10.1016/j.clinbiochem.2009.04.015.

Page BT, Casas E, Heaton MP, Cullen NG, et al. (2002). Evaluation of single-nucleotide polymorphisms in CAPN1 for association with meat tenderness in cattle. J. Anim. Sci. 80: 3077-3085. http://dx.doi.org/10.2527/2002.80123077x

Reed GH and Wittwer CT (2004). Sensitivity and specificity of single-nucleotide polymorphism scanning by highresolution melting analysis. Clin. Chem. 50: 1748-1754 http://dx.doi.org/10.1373/clinchem.2003.029751.

Reed GH, Kent JO and Wittwer CT (2007). High-resolution DNA melting analysis for simple and efficient molecular diagnostics. Pharmacogenomics 8: 597-608. DOI: 10.2217/14622416.8.6.597

Rubenson JG, Wasch KA and Riegelman RK (1989). Studying a Study and Testing a Test: How to Read the Medical Literature. 2nd edn., Boston, USA: Little, Brown and Company.

Sakaridis I, Ganopoulos I, Argiriou A and Tsaftaris A (2013). A fast and accurate method for controlling the correct labeling of products containing buffalo meat using High Resolution Melting (HRM) analysis. Meat Sci. 94: 84-88 http://dx.doi.org/10.1016/j.meatsci.2012.12.017.

Smith TPL, Casas E, Rexroad CE, Kappes SM, et al. (2000). Bovine CAPN1 maps to a region of BTA29 containing a quantitative trait locus for meat tenderness. J. Anim. Sci. 78: 2589-2594 DOI:jas.fass.org/content/78/10/2589

Schenkel FS, Miller SP, Ye X, Moore SS, et al. (2005). Association of single nucleotide polymorphisms in the leptin gene with carcass and meat quality traits of beef cattle. J. Anim. Sci. 83: 2009-2020 http://dx.doi.org/10.2527/2005.8392009x.

Schenkel FS, Miller SP, Jiang Z, Mandell IB, et al. (2006). Association of a single nucleotide polymorphism in the calpastatin gene with carcass and meat quality traits of beef cattle. J. Anim. Sci. 84: 291-299 http://dx.doi. org/10.2527/2006.842291x.

Taylor RG, Geesink GH, Thompson VF, Koohmaraie M, et al. (1995). Is Z-disk degradation responsible for postmortem tenderization? J. Anim. Sci. 73: 1351-1367 doi.org/doi:/1995.7351351x. http://dx.doi.org/10.2527/1995.7351351x

Untergasser A, Cutcutache I, Koressaar T, Ye J, et al. (2012). Primer3--new capabilities and interfaces. Nucleic Acids Res. 40: e115-e115 http://dx.doi.org/10.1093/nar/gks596.

White SN, Casas E, Wheeler TL, Shackelford SD, et al. (2005). A new single nucleotide polymorphism in CAPN1 extends the current tenderness marker test to include cattle of Bos indicus, Bos taurus, and crossbred descent. J. Anim. Sci. 83: 2001-2008 http://dx.doi.org/10.2527/2005.8392001x.

Wittwer CT, Reed GH, Gundry CN, Vandersteen JG, et al. (2003). High-resolution genotyping by amplicon melting analysis using LCGreen. Clin. Chem. 49: 853-860 http://dx.doi.org/10.1373/49.6.853.

Zhang L, Cui G, Li Z, Wang H, et al. (2013). Comparison of high-resolution melting analysis, TaqMan Allelic discrimination assay, and sanger sequencing for Clopidogrel efficacy genotyping in routine molecular diagnostics. J. Mol. Diagn. 15: 600-606 http://dx.doi.org/10.1016/j.jmoldx.2013.04.005. 